\title{
Activation of Two Different Drugs Used in Alzheimer's Disease Treatment on Human Carbonic Anhydrase Isozymes I and II Activity: an In Vitro Study
}

\author{
Alzheimer Hastalığının Tedavisinde Kullanılan İki Farklı Illacın İnsan \\ Karbonik Anhidraz I ve II İzoenzim Aktiviteleri Üzerindeki Aktivasyonu: \\ In Vitro Çalışma
}

Esra DILEK

Erzincan University, Faculty of Pharmacy, Department of Biochemistry, Erzincan, Turkey

\begin{abstract}
Objectives: Human carbonic anhydrase I and II (hCAI, II) isoenzymes were purified from human erythrocyte. Kinetic interactions between the enzymes and memantine and donepezil, two different drugs used in Alzheimer's disease (AD) treatment, were investigated.

Materials and Methods: The purification procedure was composed of preparation of homogenate (or hemolysate) and affinity chromatography on Sepharose 4B-L-tyrosine-sulfanilamide.

Results: Both drug exhibited in vitro activator effects on hCAl and II enzymes activity. Strong activations were found for these compounds: The CA values of memantine and donepezil against hCAl were $0.013 \mu \mathrm{M}$ and $1.8 \mu \mathrm{M}$, respectively. The $\mathrm{K}_{\mathrm{A}}$ values of memantine and donepezil against hCAll were $0.045 \mu \mathrm{M}$ and $3.7 \mu \mathrm{M}$, respectively.

Conclusion: Since the levels of CA isoenzymes are low in patients with AD or in the older population, increasing activities of these isoenzymes are important for these patients. The effect of these drugs used in AD treatment was thought to be caused by positive changes in the levels of carbonic anhydrase isoenzymes.
\end{abstract}

Key words: Human CAI, human CAll, enzyme activation, memantine, donepezil

ÖZ

Amaç: İnsan karbonik anhidraz I ve II (hCAI ve II) izoenzimleri insan eritrositlerinden saflaştırıldı. Alzheimer hastalı̆̆ının (AH) tedavisinde kullanılan memantin ve donepezil ilaçlarının bu enzimlerle olan kinetik etkileșimleri incelendi.

Gereç ve Yöntemler: Saflaştırma prosedürü homojenat (ya da hemolizat) hazırlama ve Sefaroz-4B-L-tirozin-sülfonamid afinite kromotografisi yönteminden oluşmaktadır.

Bulgular: Her iki ilaç da CAI ve II izoenzim aktiviteleri üzerinde in vitro aktivatör etkisi gösterdi. Bu bileșikler için güçlü aktivasyon değerleri elde edildi: hCAl izoenzimine karşı memantin ve donepezil için CA değerleri sırasıyla $0.013 \mu \mathrm{M}$ ve $1.8 \mu \mathrm{M}$. hCAll izoenzimine karşı memantin ve donepezil için $\mathrm{K}_{\mathrm{A}}$ değerleri sırasıyla $0.045 \mu \mathrm{M}$ and $3.7 \mu \mathrm{M}$.

Sonuç: AH ve yaşlı nüfusta CA izoenzim seviyeleri düșük olduğu için, bu hastalarda bu izoenzimlerin aktivitelerinin artması önem arz etmektedir. Bahsi geçen bu iki ilacın AH tedavisindeki etkisini CA izoenzimleri seviyesinde yapmış olduğu pozitif artış ile göstermiş olduğu düșünülmüștür.

Anahtar kelimeler: İnsan CAI, insan CAll, enzim aktivasyonu, memantin, donepezil 


\section{INTRODUCTION}

Carbonic anhydrases (CA) (CA, EC 4.2.1.1) are belong to family of metalloenzyme and have 16 isoforms in mammals. They catalyze from the reversible hydration of $\mathrm{CO}_{2}$ to the bicarbonate ion and protons and are expressed as $\mathrm{pH}$ regulatory enzyme in most tissues especially in erythrocytes. ${ }^{1-6}$ Many such CA isozymes which make these processes are important therapeutic targets with the potential to be inhibited/activated for the treatment of diseases such as glaucoma, edema, obesity, osteoporosis, epilepsy and cancer..$^{2-8}$ Activation of several these isoenzymes was reported to be a possible therapy for increasing of synaptic efficacy. This increase might represent the new approach for the treatment of Alzheimer's disease (AD). At the same time, it may ensure to improvement aging, spatial learning and memory therapy. ${ }^{9}$

$A D$ is characterized clinically as a progressive dementia. The neurobiological mechanisms influencing the progressive impairments in memory and intellectual performance that are the hallmarks of $A D$ are not well understood. In addition, the levels of several CA isozymes, including human carbonic anhydrase (hCAl), are diminished in patients affected by $A D$ or in the older population. ${ }^{10}$

Several classes of CA activators are known. One of them is histamine. Histamine is an organic compound including nitrogen and both mediates local immune responses and acts as a neurotransmitter. It was reported to increase the activity of CA and to attend the proton shuttling process." Function of CA activators is to bind at the entrance of the enzyme active site, at the same time to ease the proton transfer processes between active site and solvent system. Histidine, phenylalanine, sildenafil citrate have been shown to be potential activators of different CA isozymes. D-3,4-dihydroxyphenylalanine; dextrodopa (D-DOPA), L-Tyr, and 4-amino-L-Phe act as perfect activators for CAs like the histamine. But LHis, L-Trp, L-Adrenaline, and dopamine have been demonstrated weak activating effects for different $C A s^{2,12-15}$

Generally it is known that activators bind to different site from the inhibitors within the enzyme active cavity.1116 Also, they participate in facilitated the proton transfer processes between active site and solvent system, shuttling protons with groups which have an appropriate pKa such as the carboxylate groups. ${ }^{17}$

Memantine is an antagonist of $\mathrm{N}$-methyl-D-aspartate glutamate receptors as uncompetitively. It is proposed to treat of patients with moderate to severe AD. Additionally, benefits of memantine in $A D$ are reported. ${ }^{18,19}$ Memantine was chosen because of its similarity to histamine which is activator of CA isoenzymes (Figure 1). Both compounds have $-\mathrm{NH}_{2}$ group. Donepezil is a drug used in the palliative treatment of $A D$. It is approved for treatment in patients with mild to moderate $A D . .^{20,21}$

In light of the above information, we thought that these drugs could activate hCAl and II isoenzymes. We have purified hCAI and hCAll from human erythrocytes and analyzed the in vitro effects of these drugs memantine (1) and donepezil (2) on these isoenzymes. We used the esterase activity of hCAl and hCAll and 4-nitrophenyl acetate (NPA) as substrate. We are justified in our opinion. Because we found that memantine (1) and donepezil (2) are a potent activator of hCAl and hCAll.

\section{RESULTS AND DISCUSSION}

\section{CA purification, assay and activation}

We used a simple one step method which is the Sepharose4B-L-tyrosine-sulfanilamide affinity chromatography for the purification of the two CA isozymes..$^{22,23}$ These isozymes have important roles in different tissues. ${ }^{24-29}$ In many studies, they have been purified from different tissues. Theirs activity have been investigated with various chemicals, pesticides and drugs. ${ }^{22,23,30-36}$ In this study, activities of purified hCAl and hCAll isoenzymes from human erythrocytes were determined by using the esterase activity method. And we used NPA as substrate as previous study. ${ }^{36}$

Activator effects of these drugs memantine (1) and donepezil (2) on enzyme activities were tested under in vitro conditions. \%Activity / (drug concentration) curves was drawn (Figure 2, 3 ) and they was used at determination of activation constant $\left(\mathrm{K}_{A}\right)$ values of the drugs for $C A \mathrm{~A}$ and II isoenzymes. The $\mathrm{K}_{A}$ values of memantine against hCAl was found to be $0.013 \mu \mathrm{M}$ which whereas that of donepezil was of $1.8 \mu \mathrm{M}$. The $\mathrm{K}_{\mathrm{A}}$ values of memantine against hCAll were found to be $0.045 \mu \mathrm{M}$ whereas that of donepezil was of $3.7 \mu \mathrm{M}$ (Table 1).

Histamine (3) which taken as the reference compound have

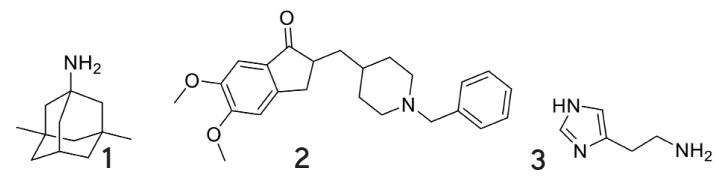

Figure 1. Chemical structures of memantine (1), donepezil (2) and histamine (3)
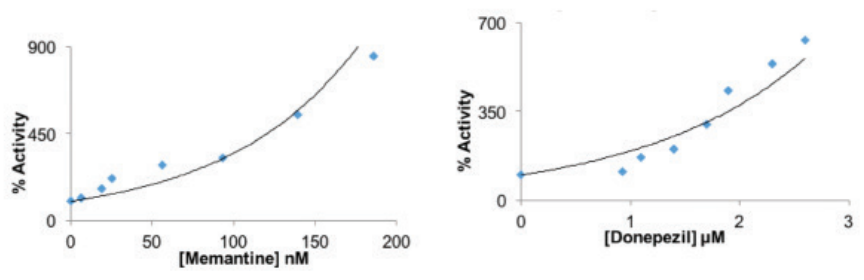

Figure 2. \%Activity / (drug concentration) curves was used at determination of $\mathrm{K}_{\mathrm{A}}$ values of the drugs for $\mathrm{CAl}$ isoenzyme
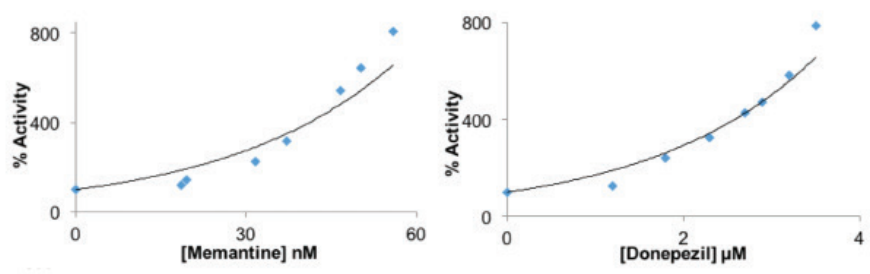

Figure 3. \%Activity / (drug concentration) curves was used at determination of $K_{A}$ values of the drugs for CAll isoenzyme 
the $\mathrm{K}_{\mathrm{A}}$ values against hCAl and hCAll of $2 \mu \mathrm{M}$, and $125 \mu \mathrm{M}$, respectively, being a highly potent activator against both the isoforms (Table 1). ${ }^{37}$ The best activator of hCAl is memantine with respective $\mathrm{K}_{\mathrm{A}}$ of $0.013 \mu \mathrm{M}$. Likewise, the best activator of hCAll is memantine with respective $\mathrm{K}_{\mathrm{A}}$ of $0.045 \mu \mathrm{M}$. Donepezil activated hCAl almost the same rate compared with histamine. But it activated hCAll more activated than histamine (Table 1). As shown in Figure 1, memantine has bicyclic structure. Other structures are planar. Memantine has been easily interacted with the amino acids in active site of CA isoenzymes and these isoenzymes have been more active.

Memantine and donepezil acted as perfect activators for CAI and II isoenzymes like LHis, L-Adrenaline, D-DOPA, L-Tyr, and 4-amino-L-Phe. But these two isoenzymes more activated than L-Trp and dopamine have been demonstrated weak activating effects for different CAs. ${ }^{2,12-15}$

We reported here the first study on the activator effects of these drugs memantine (1) and donepezil (2) on the hCA esterase activity. The structures of active substances were shown in Figure 1. Consequently, memantine and donepezil are much more potent compared with histamine. These compounds may be used as leads for developing novel activators. This study will contribute to understand the relationship between CA isoenzymes and AD. Also, it will provide important information for the diagnosis of $A D$ and its treatment.

\section{EXPERIMENTAL}

\section{Chemicals}

Sepharose-4B, protein assay reagents, 4-nitrophenylacetate and chemicals for electrophoresis were purchased from Sigma-Aldrich Co. All other chemicals were analytical grade and obtained from Merck.

\section{Purification of carbonic anhydrase}

Erythrocytes suspension was obtained from the Blood Center of the Research Hospital at Erzincan University. The red cells were washed twice with $0.9 \% \mathrm{NaCl}$, and hemolyzed with 1.5 volumes of ice-cold water. The ghost and intact cells were removed by centrifugation at $3100 \mathrm{~g}$ for $30 \mathrm{~min}$ at $4^{\circ} \mathrm{C}$. The $\mathrm{pH}$ of the hemolysate was adjusted to 8.7 with a solid Tris base, and applied to the prepared Sepharose 4B-L-tyrosine-sulfonamide affinity column equilibrated with $25 \mathrm{mM}$ Tris- $\mathrm{HCl} / 22 \mathrm{mM} \mathrm{Na}_{2} \mathrm{SO}_{4}$ $\left(\mathrm{pH}\right.$ 8.7). ${ }^{22-25}$ The hCAl and hCAll isozymes were eluted with 1 $\mathrm{M} \mathrm{NaCl} / 25 \mathrm{mM} \mathrm{Na}_{2} \mathrm{HPO}_{4}\left(\mathrm{pH}\right.$ 6.3) and 0.1 $\mathrm{M} \mathrm{CH}_{3} \mathrm{COONa} / 0.5 \mathrm{M}$ $\mathrm{NaClO}_{4}(\mathrm{pH} 5.6)$, respectively. The absorbance of the protein in

Table 1. Activation constants of hCA isozymes I, and II with memantine, donepezil and histamine

\begin{tabular}{lll}
\multirow{2}{*}{ Compound } & \multicolumn{2}{l}{$\mathrm{K}_{\mathrm{A}}(\mu \mathrm{M})$} \\
\cline { 2 - 3 } & $\mathrm{hCAl}$ & hCAll \\
\hline Memantine & 0.013 & 0.045 \\
\hline Donepezil & 1.8 & 3.7 \\
\hline Histamine & 2 & 125 \\
\hline
\end{tabular}

$\mathrm{K}_{\mathrm{A}}$ : Activation constant, hCA: Human carbonic anhydrase the column effluents was determined spectrophotometrically at $280 \mathrm{~nm} \cdot{ }^{22,23,36}$

\section{CA activation assay}

CA activity was assayed by following the change in absorbance at $348 \mathrm{~nm}$ of NPA to 4-nitrophenylate ion over a period of 3 min at $25^{\circ} \mathrm{C}$ using a spectrophotometer (Shimadzu UV-VIS) according to the method described by Verpoorte et al. ${ }^{38} \mathrm{~A}$ reference measurement was obtained by preparing the same cuvette without enzyme solution. ${ }^{39}$ The activation effects of memantine and donepezil were examined. Different activator concentrations were used. Stock solutions of activators (10 $\mathrm{mM}$ ) were prepared in distilled-deionized water and dilutions up to 0.1-0.9 $\mu \mathrm{M}$ were done thereafter with the assay buffer. Then, \%Activity / (drug concentration) curves was drawn (Figure 2, 3 ) and they was used at determination of $K_{A}$ values of the drugs for CA I and II isoenzymes.

The $\mathrm{K}_{\mathrm{A}}$ is defined similarly like the inhibition constant $\left(\mathrm{K}_{\mathrm{i}}\right)$. It is obtained with the help of the classical Michaelis-Menten equation as shown below:

$$
v=v_{\max } /\left\{1+\frac{K_{M}}{[S]\left(1+\frac{[A]_{f}}{K_{A}}\right)}\right\}
$$

$[A]_{f}$ is the free concentration of activator and can be represented in the form of the total concentration of the enzyme $\left([E]_{t}\right)$ and activator $\left([A]_{t}\right)$. Because we work at substrate concentrations considerably lower than $\mathrm{K}_{M}\left([\mathrm{~S}] \ll \mathrm{K}_{\mathrm{M}}\right)$, the obtained competitive steady-state equation for determining the activation constant is given by the following equation:

$$
\begin{aligned}
v=v_{0} \cdot K_{A} /\left\{K_{A}+[A]_{t}\right\} \\
\left.\left.\quad-0.5\left\{\left([A]_{t}+[E]_{t}+K_{A}\right)-\left([A]_{t}+[E]_{t}+K_{A}\right) 2-4[A]_{t} \cdot[E]_{t}\right) 1 / 2\right\}\right\}
\end{aligned}
$$

$v_{\mathrm{o}}$ represents the initial velocity of the enzyme-catalyzed reaction without activator. ${ }^{12,25,27}$

\section{Protein determination}

We determined amount of protein during the purification steps according to the Bradford method. We measure it spectrophotometrically at $595 \mathrm{~nm}$, using bovine serum albumin as the standard. ${ }^{36,40-43}$ We have used ten tubes with different concentrations of albumin as shown in Figure 2. Then we mixed them with the Bradford reagent (Coomassie Brilliant Blue G-250) and measured the absorbance at $595 \mathrm{~nm}$. Our unknown sample concentration was defined as $\mu \mathrm{g} / \mu \mathrm{L}$ according to standard curve in Figure 4.

\section{CONCLUSION}

The $K_{A}$ values of memantine against hCAl was found to be $0.013 \mu \mathrm{M}$ which whereas that of donepezil was of $1.8 \mu \mathrm{M}$. The $\mathrm{K}_{\mathrm{A}}$ 


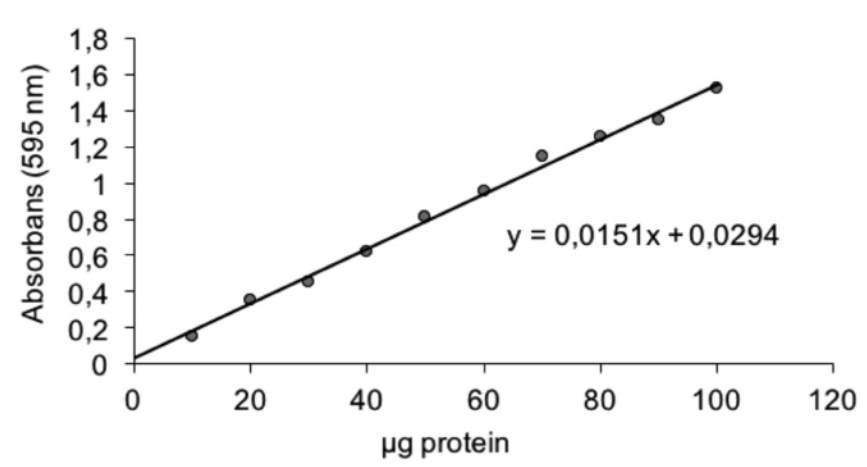

Figure 4. Protein standard curve displaying with just $\mu \mathrm{g}$ of protein at $595 \mathrm{~nm}$

values of memantine against hCAll were found to be $0.045 \mu \mathrm{M}$ whereas that of donepezil was of $3.7 \mu \mathrm{M}$ (Table 1).

We used the histamine as the reference compound. It has the $\mathrm{K}_{\mathrm{A}}$ values against $\mathrm{hCAl}$ and $\mathrm{hCAll}$ of $2 \mu \mathrm{M}$, and $125 \mu \mathrm{M}$, respectively. For two isoenzymes were reported that it is a highly potent activator. ${ }^{37}$ It was reported that histamine attends the proton shuttling process and increases the activity of CA. ${ }^{12}$

Activation of these isoenzymes can be a potential target for drug development because of the physiological relevance of $\mathrm{CAs}^{2}{ }^{2} \mathrm{CA}$ activators may be designed as a derivative for increasing of synaptic efficacy. ${ }^{37}$ The pharmacological effects of memantine and donepezil not yet been developed clinically for hCA I and hCA II isoenzymes. Thus, in the near future, the novel therapeutic applications will make for enzyme activators.

Conflict of Interest: No conflict of interest was declared by the author.

\section{REFERENCES}

1. Imtaiyaz Hassan M, Shajee B, Waheed A, Ahmad F, Sly WS. Structure, function and applications of carbonic anhydrase isozymes. Bioorg Med Chem. 2013;21:1570-1582.

2. Supuran CT, Vullo D, Manole G, Casini A, Scozzafava A. Designing of novel carbonic anhydrase inhibitors and activators. Curr Med Chem Cardiovasc Hematol Agents. 2004;2:49-68.

3. Supuran CT, Scozzafava A. Carbonic anhydrases as targets for medicinal chemistry. Bioorg Med Chem 2007;15:4336-4350.

4. Supuran CT. Carbonic anhydrases: novel therapeutic applications for inhibitors and activators. Nat Rev Drug Discov. 2008;7:168-181.

5. Innocenti A, Vullo D, Scozzafava A, Supuran CT. Carbonic anhydrase inhibitors: interactions of phenols with the 12 catalytically active mammalian isoforms (CAI-XIV). Bioorg Med Chem Lett. 2008;18:1583-1587.

6. Oztürk Sarikaya SB, Topal F, Sentürk M, Gülçin I, Supuran CT. In vitro inhibition of $\alpha$-carbonic anhydrase isozymes by some phenolic compounds. Bioorg Med Chem Lett. 2011;21:4259-4262.

7. Nair SK, Ludwig PA, Christianson DW. Two site binding of phenol in the active site of human carbonic anhydrase II: structural implications for substrate association. J Am Chem Soc. 1994;116:3659-3660.

8. Casey JR. Why bicarbonate? Biochem Cell Biol. 2006;84:930-939.

9. Sun MK, Alkon DL. Carbonic anhydrase gating of attention: memory therapy and enhancement. Trends Pharmacol Sci. 2002;23:83-89.
10. Sultana R, Boyd-Kimball D, Poon HF, Cai J, Pierce WM, Klein JB, Merchant M, Markesbery WR, Butterfield DA. Redox proteomics identification of oxidized proteins in Alzheimer's disease hippocampus and cerebellum: an approach to understand pathological and biochemical alterations in AD. Neurobiology of Aging. 2006;27:1564-1576.

11. Briganti F, Mangani S, Orioli P, Scozzafava A, Vernaglione G, Supuran CT. Carbonic anhydrase activators: $X$-ray crystallographic and spectroscopic investigations for the interaction of isozymes I and II with histamine. Biochemistry. 1997;36:10384-10392.

12. Temperini C, Scozzafava A, Vullo D, Supuran CT. Carbonic anhydrase activators. Activation of isozymes I, II, IV, VA, VII, and XIV with I- and $d$-histidine and crystallographic analysis of their adducts with isoform II: engineering proton-transfer processes within the active site of an enzyme. Chemistry. 2006;12:7057-7066.

13. Abdülkadir Coban T, Beydemir S, Gülcin I, Ekinci D, Innocenti A, Vullo D, Supuran CT. Sildenafil is a strong activator of mammalian carbonic anhydrase isoforms I-XIV. Bioorg Med Chem. 2009;17:5791-5795.

14. Nishimori I, Onishi S, Vullo D, Innocenti A, Scozzafava A, Supuran CT. Carbonic anhydrase activators: the first activation study of the human secretory isoform VI with amino acids and amines. Bioorg Med Chem. 2007; 15:5351-5357.

15. Dessirier JM, Simons CT, Carstens MI, O'Mahony M, Carstens E. Psychophysical and neurobiological evidence that the oral sensation elicited by carbonated water is of chemogenic origin. Chem Senses. 2000;25:277-284.

16. Ilies MI, Banciu MD, llies MA, Scozzafava A, Caproiu MT, Supuran CT. Carbonic anhydrase activators: design of high affinity isozymes I, II, and IV activators, incorporating tri-/tetrasubstituted-pyridinium-azole moieties. J Med Chem. 2002;45:504-510.

17. Briganti $F$, laconi $V$, Mangani S, Orioli P, Scozzafava A, Vernaglione G, Supuran CT. A ternary complex of carbonic anhydrase: X-ray crystallographic structure of the adduct of human carbonic anhydrase II with the activator phenylalanine and the inhibitor azide. Inorg Chim Acta. 1998:295-300.

18. Winblad B, Poritis N. Memantine in severe dementia: results of the 9M-Best Study (Benefit and efficacy in severely demented patients during treatment with memantine). Int J Geriatr Psychiatry. 1999;14:135146.

19. Wilkinson D, Andersen HF. Analysis of the effect of memantine in reducing the worsening of clinical symptoms in patients with moderate to severe Alzheimer's disease. Dement Geriatr Cogn Disord. 2007;24:138-145.

20. Winblad B, Black SE, Homma A, Schwam EM, Moline M, Xu Y, Perdomo CA, Swartz J, Albert K. Donepezil treatment in severe Alzheimer's disease: a pooled analysis of three clinical trials. Curr Med Res Opin. 2009;25:2577-2587.

21. Birks J, Harvey RJ. Donepezil for dementia due to Alzheimer's disease. Cochrane Database Syst Rev. 2006:CD001190.

22. Çağlar S, Dilek E, Çağlar B, Adiguzel E, Temel E, Buyukgungor O, Tabak A. New metal complexes with diclofenac containing 2-pyridineethanol or 2-pyridinepropanol: synthesis, structural, spectroscopic, thermalproperties, catechol oxidase and carbonic anhydrase activities. Journal of Coordination Chemistry. 2016;69:3321-3335.

23. Burmaoğlu S, Dilek E, Yılmaz AO, Supuran CT. Synthesis of two phloroglucinol derivatives with cinnamyl moieties as inhibitors of the carbonic anhydrase isozymes I and II: an in vitro study. J Enzyme Inhib Med Chem. 2016;31(Suppl 2)208-212. 
24. Supuran CT. Carbonic anhydrases: novel therapeutic applications for inhibitors and activators. Nat Rev Drug Discov. 2008;7:168-181.

25. Sly WS, Hu PY. Human carbonic anhydrases and carbonic anhydrase deficiencies. Annu Rev Biochem. 1995;64:375-401.

26. Ozensoy O, Arslan O, Sinan SO. A new method for purification of carbonic anhydrase isozymes by affinity chromatography. Biochemistry. 2004;69:216-219.

27. (a) Parkkila S, Parkkila AK, Carbonic anhydrase in the alimentary tract. Roles of the different isozymes and salivary factors in the maintenance of optimal conditions in the gastrointestinal canal. Scand J Gastroenterol. 1996;31:305-317. (b) Pastorekova S, Parkkila S, Pastorek J, Supuran CT. Carbonic anhydrases: current state of the art, therapeutic applications and future prospects. J Enzyme Inhib Med Chem. 2004;19:199-229.

28. Bülbül M, Hisar O, Beydemir S, Ciftçi M, Küfrevioğlu OI. The in vitro and in vivo inhibitory effects of some sulfonamide derivatives on rainbow trout (Oncorhynchus mykiss) erythrocyte carbonic anhydrase activity. J Enzyme Inhib Med Chem. 2003;18:371-375.

29. (a) Svastová E, Hulíková A, Rafajová M, Zat'ovicová M, Gibadulinová A, Casini A, Cecchi A, Scozzafava A, Supuran CT, Pastorek J, Pastoreková S. Hypoxia activates the capacity of tumor-associated carbonic anhydrase IX to acidify extracellular pH. FEBS Lett. 2004;577:439445. (b) Cecchi A, Hulikova A, Pastorek J, Pastoreková S, Scozzafava A, Winum JY, Montero JL, Supuran CT. Carbonic anhydrase inhibitors. Design of fluorescent sulfonamides as probes of tumor-associated carbonic anhydrase IX that inhibit isozyme IX-mediated acidification of hypoxic tumors. J Med Chem. 2005;48:4834-4841.

30. Çelik I, Çamas H, Arslan O, Küfrevioglu Öi. The effect of some pesticides on human and bovine erythrocyte carbonic anhydrase enzyme activities in vitro. J Environ Sci Health. 1996;31:2651-2657.

31. Vitale AM, Monserrat JM, Castilho P, Rodriguez EM. Inhibitory effects of cadmium on carbonic anhydrase activity and ionic regulation of the estuarine crab Chasmagnathus granulata (Decapoda, Grapsidae), Comp Biochem Physiol C Pharmacol Toxicol Endocrinol. 1999;122:121-129.

32. Gervais MR, Tufts BL. Characterization of carbonic anhydrase and anion exchange in the erythrocytes of bowfin (Amia calva), a primitive airbreathing fish. Comp Biochem Physiol A. 1999;23:343-350.
33. Hochster RM, Kates M, Quastel JH. Metabolic Inhibitors (ed). Academic Press; New York; 1973:66-82.

34. Ozdemir H, Uğuz MT. In vitro effects of some anaesthetic drugs on lactoperoxidase enzyme activity. J Enzyme Inhib Med Chem. 2005;20:491-495.

35. Christensen GM, Olson D, Riedel B. Chemical effects on the activity of eight enzymes: a review and a discussion relevant to environmental monitoring. Environ Res. 1982;29:247-255.

36. Bayram E, Senturk M, Kufrevioglu OI, Supuran CT. In vitro inhibition of salicylic acid derivatives on human cytosolic carbonic anhydrase isozymes I and II. Bioorg Med Chem. 2008;16:9101-9105.

37. Bertucci A, Zoccola D, Tambutté S, Vullo D, Supuran CT. Carbonic anhydrase activators. The first activation study of a coral secretory isoform with amino acids and amines. Bioorg Med Chem. 2010;18:23002303.

38. Verpoorte JA, Mehta S, Edsall JT. Esterase activities of human carbonic anhydrases B and C. J Biol Chem. 1967;242:4221-4229.

39. Innocenti A, Scozzafava A, Parkkila S, Pucceti L, De Simone G, Supuran $\mathrm{CT}$. Investigations of the esterase, phosphatase, and sulfatase activities of the cytosolic mammalian carbonic anhydrase isoforms I, II, and XIII with 4-nitrophenyl esters as substrates. Bioorg Med Chem Lett. 2008;18:2267-2271.

40. Dilek EB, Küfrevioğlu Öi, Beydemir Ş. Impacts of some antibiotics on human serum paraoxonase 1 activity. J Enzyme Inhib Med Chem. 2013;28:758-764.

41. Dilek E, Caglar S. Effects of mono and dinuclear copper (II) complexes derived from non-steroidal anti-inflammatory drug naproxen on human serum paraoxanase1 (PON1) activity. Int J Pharm Chem. 2015;5:189-195.

42. Dilek E, Polat MF. In Vitro Inhibition Of Three Different Drugs Used In Rheumatoid Arthritis Treatment On Human Serum Paraoxanase 1 Enzyme Activity. Protein Pept Lett. 2016;23:3-8.

43. Caglar S, Dilek E, Hamamci Alisir S, Çaglar B. New copper (II) complexes including pyridine-2,5-dicarboxylic acid: synthesis, spectroscopic, thermal properties, crystal structure and how these complexes interact with purified PON 1 enzyme, Journal of Coordination Chemistry. 2016;69:321-325. 